Abstracts of offered papers and posters

Field Excursion

Index 
The five offered papers at the symposium cover wide-ranging subjects and although extensions of work already in progress they are important enough to include. They up-date the reader with new facts and pertinent references. To these is added an abstract of a paper by Ian Hunter on the creative, economic and environmental application of willow.

The texts accompanying the various posters are brought together here as a single unit for easy reference to add to this Volume's value as a source of information on willow for many years to come. The subjects span aspects of genetics, phytogeography, taxonomy and biochemistry to willows as a source of energy. It is particularly gratifying that they include the work of scientists in many countries within and outwith Western Europe.

Demonstrations on some amenity uses of willow (L. Balfour; Jennifer Woods), cell-grown plants (R. Ogilvy), energy forestry in Sweden (Sennerby-Forsse \& N.-E. Nordh) and mapping willows in the Iberian Peninsula (Paloma Blanco) added to the completeness of the symposium but are not documented herein.

ROY WATLING

\section{ABSTRACTS OF OFFERED PAPERS}

\section{Pests and diseases in Salix biomass plantations - and plant breeding efforts to reduce them}

\section{Inger Åhman}

Resistance Breeding Department, Svalöf AB, S-268 00 Svalöv, Sweden

When starting a breeding programme for increased plant resistance, key pests and pathogens must be identified. This may be difficult with a relatively new crop for biomass production such as Salix. However, small-scale biomass plantations in Europe during the last 15-20 years have given us some experience as to which organisms may cause economical damage. Leaf rusts (Melampsora spp.) and subsequent stem infections by other fungi are the most serious threat to successful biomass production at present. Browsing mammals and insects that disrupt terminal growth also cause damage, particularly in nurseries for production of stem cuttings. Sap-sucking aphids and leafhoppers, and leaf-eating beetles and moths can be very abundant, but their effects on wood production are less clear.

In the Swedish resistance breeding programme most effort is spent in selecting Salix viminalis-clones with higher resistance to Melampsora. In 1988 we were reminded of our short term experience with Salix biomass plantations when a 'new' 
species of gall midge killing the terminal leaf buds of $S$. viminalis $L$. became very abundant in southern Sweden, and has been ever since. The attack rate of this midge is also considered when breeding material is selected. To further increase the genetic base in the breeding material interspecific crosses are now being made for example between European $S$. viminalis and $S$. schwerinii E. Wolf from the Soviet Union.

\section{Variability in species of the genus Salix with particular reference to cultivated taxa}

\section{J. Chmelar̆}

University Botanical Gardens - Arboretum, Brno, Czechoslovakia

The intraspecific variability was studied in the genus Salix. In addition to the observations made in the field and the evaluations of herbarium specimens, the willows growing in the Brno Botanical Garden - Arboretum (affiliated to the Brno College of Agriculture, Czechoslovakia) in particular were studied. Among the several hundred specimens it was possible to detect rigid taxa featuring very low variability, e.g. Salix caesia L., S. myrtilloides L., S. vestita Parsh. on the one hand and species that show an extremely wide variability in certain morphological characteristics on the other, e.g. Salix babylonica L., S. alba L., S. purpurea L.

A survey of the willow cultivars has been completed with emphasis on their individual characteristics, e.g. type of growth, difference in foliage, size of catkins, colouring of twigs, and has detected additional attractive cultivars. There is a possibility in the future to introduce into horticulture a group of new willows suitable for cultivation.

\section{Growth of two arctic/alpine willows, Salix setchelliana (Alaska, U.S.A.) and S. polaris (Kola Peninsula, U.S.S.R.)}

\section{A. Douglas}

Biology Department, Boise State University, Boise, ID. 83725 U.S.A.

Salix setchelliana Ball, a prostrate willow of Alaskan glacial river gravel bars, grows clonally from a peripherally expanding horizontal root-system. To understand the species' success in its temporary habitat, its architectural system was examined during the period 1987-89, and several architectural parameters quantified. This analysis indicated that clones appear to change in time from a 'guerrilla' strategy of environmental exploration to more of a 'battalion' strategy of increased branching of the underground system (Douglas 1991). A similar study of $S$. polaris Wahl., a widely distributed species of tundra habitats, was initiated in 1991. Plants growing in two locations in the Xibini Mountains, U.S.S.R., and in two size categories were excavated and their architectural form described. Data-analysis is in progress. This examination of $S$. polaris will help determine if the temporal changes in growth strategy seen in $S$. setchelliana are typical of low-growing northern willows. 